
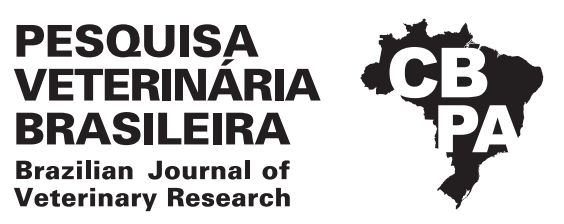

Pesq. Vet. Bras. 38(7):1358-1364, julho 2018 DOI: 10.1590/1678-5150-PVB-55141

Original Article

ISSN 0100-736X (Print)

ISSN 1678-5150 (Online)

\title{
Detection of Staphylococcus aureus, Streptococcus agalactiae and Escherichia coli in Brazilian mastitic milk goats by multiplex-PCR ${ }^{1}$
}

\author{
Gustavo P. Machado ${ }^{2}$, Rodrigo C. Silva ${ }^{3}$, Felipe F. Guimarães ${ }^{4}$, Anelise Salina ${ }^{4}$ \\ and Hélio Langoni* ${ }^{4 *}$
}

\begin{abstract}
Machado G.P., Silva R.C., Guimarães F.F., Salina A. \& Langoni H. 2018. Detection of Staphylococcus aureus, Streptococcus agalactiae and Escherichia coli in Brazilian mastitic milk goats by multiplex-PCR. Detecção de Staphylococcus aureus, Streptococcus agalactiae e Escherichia coli em leite caprino mastítico no Brasil, por multiplex-PCR. Pesquisa Veterinária Brasileira 38(7):1358-1364. Departamento de Higiene Veterinária e Saúde Pública, Universidade Estadual Paulista, Rua Prof. Dr. Walter Maurício Correa s/n, Universidade Estadual Paulista, Botucatu, SP 18618-681, Brazil. E-mail: hlangoni@fmvz.unesp.br

This study evalueted the prevalence of Staphylococcus aureus, Streptococcus agalactiae and Escherichia coli in milk samples from 257 goats (513 half-udders) and ten bulk tanks, from ten dairy goat farms of São Paulo State, Brazil, by multiplex-PCR. The samples were screened by microbiological culture (gold-standard), and tested by different multiplex-PCR protocols for the detection of each bacterium. A total of 178 half-udders resulted positive by microbiological culture, with coagulase-negative staphylococci (70\%), S. aureus (13.5\%), S. intermedius (7.9\%), and Enterobacteriaceae (4\%) the prevalent pathogens. In other way, multiplex-PCR detected 173 pathogens in 151/523 (28.9\%; CI95\% 25.2-32.9\%) milk samples $144 / 513(28.1 \%)$ half-udders and 7/10 (70\%) bulk tanks, with E. coli $(86 / 162,51.9 \%)$ and S. aureus $(50 / 162,30.9 \%)$ the prevalent ones in half-udders, and S. aureus $(6 / 10,60 \%)$ and E. coli $(4 / 5,36.4 \%)$ in bulk tanks. Multiplex-PCR showed a high performance for the detection of three bacteria at a time in mastitic goat milk direct from half-udders or bulk tanks. Thus, this multiplex-PCR protocol proved to be an adequate tool for the identification of the most common mastitis pathogens, independent of their phenotypic characteristics in the diagnosis of clinical mastitis in goats, allowing a continuous and better vigilance and monitoring the herd, being included in quality programs.
\end{abstract}

INDEX TERMS: Staphylococcus aureus, Streptococcus agalactiae, Escherichia coli, mastitis, milk, goats, multiplex-PCR, bulk tanks, microbiological culture.

RESUMO.- [Detecção de Staphylococcus aureus, Streptococcus agalactiae e Escherichia coli em leite caprino mastítico no Brasil, por multiplex-PCR.] Este estudo avaliou por multiplex-PCR a prevalência de Staphylococcus aureus,

\footnotetext{
${ }^{1}$ Received on June 29, 2017.

Accepted for publication on January 8, 2018.

2 Médico Veterinário, Rua Rodrigues Alves 227, Centro, Itápolis, SP 14900-000, Brazil.

${ }^{3}$ Centro de Ciências Agrárias, Universidade Estadual do Norte do Paraná, Campus Luiz Meneghel, sala 88, Rodovia BR-369 Km 54, Vila Maria, Bandeirantes, PR 86360-000, Brazil.

${ }^{4}$ Departamento de Higiene Veterinária e Saúde Pública, Universidade Estadual Paulista (Unesp), Rua Prof. Dr. Walter Maurício Correa s/n, Botucatu, SP 18618-681, Brazil. *Corresponding author: hlangoni@fmvz.unesp.br
}

Streptococcus agalactiae e Escherichia coli em amostras de leite de 257 caprinos (513 tetos) e dez tanques de expansão, em dez fazendas leiteiras do estado de São Paulo, Brasil. As amostras foram triadas por cultura microbiológica (padrão-uro) e testadas por diferentes protocolos multiplex-PCR para a detecção de cada bactéria. Um total de 178 amostras de leite foram positivos na cultura microbiológica, com estafilococos coagulase-negativos (70\%), S. aureus (13,5\%), S. intermedius $(7,9 \%)$ e Enterobacteriaceae (4\%) como patógenos prevalentes. Por outro lado, a PCR multiplex detectou 173 patógenos em 151/523 (28,9\%, IC95\% 25,2-32,9\%) amostras de leite, $144 / 513(28,1 \%)$ amostras de tetos e $7 / 10(70 \%)$ em tanques de expansão, E. coli (86/162, 51,9\%) e S. aureus $(50 / 162,30,9 \%)$ foram identificados nas amostras de tetos 
e $S$. aureus $(6 / 10,60 \%)$ e $E$. coli $(4 / 5,36,4 \%)$ em tanques expansão. Multiplex-PCR mostrou um alto desempenho para a detecção das três bactérias em leite de cabra com mastite ou em tanques de expansão. Dessa forma, este protocolo multiplex-PCR provou ser uma ferramenta adequada para a identificação dos patógenos mais comuns da mastite, independentemente de suas características fenotípicas no diagnóstico de mastite clínica em caprinos, permitindo uma vigilância contínua e melhor acompanhamento do rebanho, sendo incluído em programas de qualidade.

TERMOS DE INDEXAÇÃO: Staphylococcus aureus, Streptococcus agalactiae, Escherichia coli, leite, caprinos, mastítis, multiplex-PCR, tanques de expansão, cultura microbiológica.

\section{INTRODUCTION}

Mastitis is an inflammation of the mammary gland, caused by over 150 different contagious or environmental micro-organisms (Kuang et al. 2009). Although a wide spectrum of bacterial species have been identified as causative agents of mastitis, only few species of staphylococci, streptococci and coliforms present economic and epidemiological importance. In many countries, Staphylococcus aureus is the most significant pathogen causing intra-mammary infection in dairy animals (Graber et al. 2007, Kuang et al. 2009). In addition, coagulase-negative staphylococci (CNS), a group of Staphylococcus spp., have become the predominant pathogens causing subclinical or clinical mastitis in several countries (Pyorala \& Taponen 2009, Schukken et al. 2009).

Streptococcus agalactiae is an important pathogen in caprine mastitis, causing fibrosis and reduced milk production (Bergonier et al. 2003). Escherichia coli is one of the main pathogens associated with environmental mastitis, causing to a wide range of systemic disease, from acute to severe (Gunther et al. 2011). Raw milk and dairy products made from nonpasteurized milk have been responsible for $S$. aureus and E. coli outbreaks and could represent a potential hazard for consumers (Little et al. 2008). Accurate species identification is essential to enable rapid intervention and the use of the appropriate treatment for the control of caprine mastitis (Ghebremedhin et al. 2008).

As the number of causative agents of mastitis is large and many of these are genetically closely related, the differentiation of the different species within this large group is complex (Koskinen et al. 2009). Moreover, identification based on phenotypic differences is unreliable because there is lack of unique biochemical markers for species identification (Capurro et al. 2009). Although DNA sequence-based molecular methods have proved to be proficient approach for species identification, reliable, feasible, fast and accurate identification methods still remain a necessity (Cremonesi et al. 2009, Zadoks \& Watts 2009).

In this way, the present study was aimed to determine the prevalence of $S$. aureus, S. agalactiae and E. coli in milk samples from goats and bulk tanks by the use of a sensitive and specific multiplex-PCR assay for the simultaneous detection of these causative agents of caprine mastitis.

\section{MATERIALS AND METHODS}

Sampling. A total of 508 half-udder milking samples (254 goats) and five bulk tanks were sampled in an unique timepoint for each one of 10 flocks during the lactation period. The first few streams of milk were discarded, and duplicate half-udder milk sample were aseptically collected into sterile tubes after cleaning and disinfection of each teat end. One sample $(10 \mathrm{~mL})$ was used for bacteriological culture and molecular analysis. The milk sample was stored at $4^{\circ} \mathrm{C}$.

Microbiological methods. Each half-udder milk sample was homogenized and $10 \mu \mathrm{L}$ were inoculated onto $5 \%$ Sheep Blood Agar (SBA) and MacConkey Agar (MA) plates. The plates were incubated aerobically at $37^{\circ} \mathrm{C}$ and examined after 24,48 and 72 hours. Bacterial colonies were isolated on brain heart infusion agar (BHI) (Oxoid, UK), and identified using routinely microbiological procedures such as colony morphology, microscopic characteristics and Gram staining, hemolysis pattern on SBA, catalase and oxidase reactions. Additional classification was carried out by specific biochemical sets for each bacteria Staphylococcus aureus, Streptococcus agalactiae (Quinn et al. 2005) and E. coli (Trabulsi et al. 2005).

Molecular methods. The milk samples were stored and frozen in 1.5-mL DNase and RNase free centrifuge tubes at $-80^{\circ} \mathrm{C}$. The extraction of DNA from milk samples of 10 dairy goats farms were performed using illustra genomicPrep blood Mini Spin Kit (GE Healthcare, USA) according to the instructions of the manufacturer with some modifications. All milk samples of half-udders, bulk tanks, and ATCC standards were submitted to the DNA extraction.

The analytical sensitivity for each analyzed bacterium, each bacterium was inoculated into BHI broth and incubated for 24 hours at $37^{\circ} \mathrm{C}$. After, $900 \mu \mathrm{L}$ sterile ultrapure water were aliquoted into sterile microtubes free DNase and RNase, and other microtubules $900 \mu \mathrm{L}$ goat milk long life commercialized in Botucatu, SP. An aliquot of $100 \mu \mathrm{L}$ of the $10^{9}$ bacterias $/ \mathrm{mL}^{-1}$ suspension, obtained according to the McFarland scale $4\left(1.2 \times 10^{9}\right.$ bacteria $\left./ \mathrm{mL}^{-1}\right)$ was diluted in $900 \mu \mathrm{L}$ of ultrapure water in order to obtain a serial dilution, in water, of $10^{8}, 10^{7}, 10^{6}, 10^{5}, 10^{4}, 10^{3}, 10^{2}, 10^{1}$ and $10^{0}$ bacterias $/ \mathrm{mL}^{-1}$. Likewise, the same suspension $10^{8}$ bacterias $/ \mathrm{mL}^{-1}$ was diluted in $900 \mu \mathrm{L}$ goat milk sample in order to obtain a serial dilution of $10^{8}, 10^{7}, 10^{6}, 10^{5}$, $10^{4}, 10^{3}, 10^{2}, 10^{1}$, and $10^{0}$ bacteria $/ \mathrm{mL}^{-1}$.

All samples were assayed to PCR detection of S. aureus, S. agalactiae and E. coli by single PCR protocols firstly and, then, multiplex-PCR by the use of the primers described on Table 1 . The primers targeted the species-specific regions of the DNA coding for 16S and 23S rRNA (16S or 23S rRNA), according to Straub et al. (1999), Riffon et al. (2001) and Chotár et al. (2006), and the encoding gene sip (surface immunogenic protein), designated as Sequence Specific Sip (SSS) for GBS (Lancefield Group B Streptococcus), according to Chotár et al. (2006). The concentrations of reagents used in the multiplex-PCR was used to compare the Straub et al. (1999) and Chotár et al. (2006) studies. Each $0.2-\mathrm{mL}$ microtube received $25 \mu \mathrm{L}$ of mix containing 10x magnesium-free PCR buffer ( $50 \mathrm{mM} \mathrm{KCl}, 10 \mathrm{mM}$ Tris-HCl pH8.0), $1.5 \mathrm{mM} \mathrm{MgCl}, 0.2 \mathrm{mM}$ desoxynucleotide solution, $0.5 \mathrm{U}$ (Straub et al. 1999) Platinum Taq DNA polymerase (Life Technologies, USA), $10 \mu \mathrm{M}$ (Straub et al. 1999) or $25 \mu \mathrm{M}$ (Chotár et al. 2006) each oligonucleotide (Integrated DNA Technologies, USA) 10ng sample, and ultrapure water q.s.p (Life Technologies, USA). All reactions were run in a Mastercycler EP gradient thermocycler (Eppendorf, USA).

Two cycling protocols were tested: the first, described by Chotár et al. (2006), using the primers SAU1 and SAU2, SIP3 and SIP4 or SAGA1 and SAGA2, Ecoli1 and Ecoli2, consisted of an initial incubation of 5 minutes at $96^{\circ} \mathrm{C}$, followed by 30 cycles of 1 minute at $96^{\circ} \mathrm{C}, 1$ minute at $55^{\circ} \mathrm{C}$ and 2 minutes $72^{\circ} \mathrm{C}$, with a final incubation of 8 minutes at $72^{\circ} \mathrm{C}$. The second, described by Straub et al. (1999), used the primers STAUR4 and STAUR6, SIP3 and SIP4, Ecoli1 and Ecoli2, and consisted of an initial incubation of 5 minutes at $96^{\circ} \mathrm{C}$, followed by 37 cycles of 1 minute at $96^{\circ} \mathrm{C}, 1 \mathrm{~min}$ (gradient annealing test: $56^{\circ} \mathrm{C}, 56.2^{\circ} \mathrm{C}, 56.6^{\circ} \mathrm{C}, 57.3^{\circ} \mathrm{C}, 58.2^{\circ} \mathrm{C}, 59.3^{\circ} \mathrm{C}, 60.4^{\circ} \mathrm{C}, 61.5^{\circ} \mathrm{C}, 62.5^{\circ} \mathrm{C}$, 
Table 1. Primers used for amplification of Staphylococcus aureus, Streptococcus agalactiae and Escherichia coli DNA in goat milk samples by multiplex-PCR

\begin{tabular}{|c|c|c|c|c|c|c|}
\hline Agent & Target & Primers $^{\mathrm{a}}$ & Primers $^{b}$ & Sequences $\left(5^{\prime}-3^{\prime}\right)$ & Size (pb) & Reference \\
\hline \multirow[t]{4}{*}{ S. aureus } & 23S rRNA & Sau 327 & SAU1 & GGACGACATTAGACGAATCA & 1300 & Riffon et al. (2001) \\
\hline & & Sau 1645 & SAU2 & CGGGCACCTATTTTCTATCT & & Chotár et al. (2006) \\
\hline & $23 \mathrm{~S}$ rRNA & STAUR4 & - & ACGGAGTTACAAAGGACGAC & 1250 & Straub et al. (1999) \\
\hline & & STAUR6 & - & AGCTCAGCCTTAACGAGTAC & & \\
\hline \multirow[t]{4}{*}{ S. agalactiae } & $16 \mathrm{~S}$ rRNA & Sag 432 & SAGA1 & CGTTGGTAGGAGTGGAAAAT & 590 & Riffon et al. (2001) \\
\hline & & Sag 1018 & SAGA2 & CTGCTCCGAAGAGAAAGCCT & & Chotár et al. (2006) \\
\hline & $\operatorname{sip}^{*}$ & SIP3 & SIP3 & TGAAAATGCAGGGCTCCAACCTCA & 293 & Chotár et al. (2006) \\
\hline & & SIP4 & SIP4 & GATCTGGCATTGCATTCCAAGTAT & & \\
\hline \multirow[t]{2}{*}{ E. coli } & 23S rRNA & Eco 2083 & Ecoli1 & GCTTGACACTGAACATTGAG & 660 & Riffon et al. (2001) \\
\hline & & Eco 2745 & Ecoli2 & GCACTTATCTCTTCCGCATT & & Chotár et al. (2006) \\
\hline
\end{tabular}

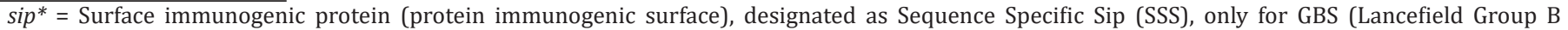

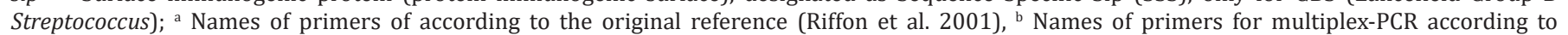
Chotár et al. (2006).

$63.4^{\circ} \mathrm{C}, 63.8^{\circ} \mathrm{C}, 64^{\circ} \mathrm{C}$ ) and 2 minutes at $72^{\circ} \mathrm{C}$ with final incubation of 8 minutes at $72^{\circ} \mathrm{C}$.

Aliquots of $8 \mu \mathrm{L}$ of the amplicons were mixed to $2 \mu \mathrm{L}$ bromophenol blue solution and subjected to horizontal electrophoresis in 1.5\% agarose gel containing 0.3 ethidium bromide $\mu \mathrm{L} / \mathrm{mL}^{-1}$ diluted in $1 \mathrm{X}$ tris-borate-EDTA (TBE). The amplification products were visualized and photographed in a digital photo documentation system, Gel-Doc System it (UVP, USA), VisionWorks LS software.

Statistical analysis. Descriptive statistics PROC FREQ (SAS Institute 2009) were produced to characterize the studied population, describe and estimate the prevalence of the etiological causative agents of mastitis. Chi-square or Fisher's exact test (PROC FREQ, SAS Institute 2009) was used to test the hypothesis that the prevalence of mastitis was heterogenous among the farms. The concordance between the results of microbiological culture and multiplex-PCR, for half-udders and bulk tank, was analyzed by the Cohen's kappa index. The statistics performance of the multiplex-PCR was analyzed by the use of Mackinnon (2000) spreadsheet. Statistical significance was defined as $P<0.05$.

\section{Microbiological culture}

By microbiological culture, 178/513 (34.7\%; CI95\% 30.6-38.8\%) half-udders presented positive results, with CNS ( $\mathrm{n}=123 ; 70 \%)$, Staphylococcus aureus $(\mathrm{n}=24 ; 13.5 \%)$, Streptococcus intermedius ( $\mathrm{n}=14 ; 8.0 \%)$, and Enterobacteriaceae $(\mathrm{n}=7 ; 4 \%)$ the prevalent pathogens observed. Additionally, Corynebacterium spp. $(\mathrm{n}=3 ; 1.7 \%)$, S. hyicus $(\mathrm{n}=3 ; 1.7 \%)$, Streptococcus spp. $(\mathrm{n}=1 ; 0.6 \%)$, Micrococcus spp. $(\mathrm{n}=1 ; 0.6 \%)$, Staphylococcus schleiferi subsp. coagulans $(\mathrm{n}=1 ; 0.6 \%)$ and Staphylococcus lutrae ( $\mathrm{n}=1 ; 0.6 \%)$ were identified. Considering the frequency in all 513 studied half-udders the respective percentage was $24 \%$ CNS, $4.7 \%$ S. aureus, $2.73 \%$ S. intermedius, $1.4 \%$ Enterobacteriaceae and $0.2 \%$ Streptococcus spp. (Table 2).

Additionally, the frequency of CNS, S. intermedius, $S$. aureus, Corynebacterium spp., Enterobacteriaceae, S. hyicus, and Streptococcus spp. ranged from 0 to $50 \%, 0$ to $13.1 \%, 0$ to $12.9 \%$, 0 to $5 \%, 0$ to $3.4 \%, 0$ to $2.6 \%$, and 0 to $2.2 \%$ respectively, among the dairy goat farms. The distribution of isolated pathogens from the milk samples were not homogenous among the farms $(P<0.01)$.

\section{Multiplex-PCR}

Specific PCR was performed for each agents using the protocol and primers described by Chotár et al. (2006), which uses an annealing temperature of $55^{\circ} \mathrm{C}$. When examining the efficiency of the primer in the detection of the agent in water samples and goat milk samples contaminated, was observed that the sets of primers SAU1 and SAU2, SAGA1 and SAGA2, and Ecol1 and Ecol2 detected until $10^{\circ}$ bacteria $/ \mathrm{mL}^{-1}$ in water, but when analyzing milk samples contaminated, the same primers detected a minimum of $10^{2}$ bacteria. $\mathrm{mL}^{-1}$ (Staphylococcus aureus), $10^{4}$ bacteria. $\mathrm{mL}^{-1}$ (Streptococcus agalactiae), and $10^{0}$ bacteria. $\mathrm{mL}^{-1}$ (E. coli). The low analytical sensitivity observed for $S$. aureus and $S$. agalactiae may be suggested by the low frequency of copies of regions flanked by primers SAU1 and SAU2, and mainly SAGA1 and SAGA2, used in the work described by Chotár et al. (2006).

Based on these results, we tested the set of primers STAUR4 and STAUR6, described by Straub et al. (1999) for detection of S. aureus, and SIP3 and SIP4 described by Chotár et al. (2006) for detection of $S$. agalactiae. Chotár et al. (2006) standardized the multiplex-PCR protocol used previously. We reused the same protocol modifying primers specific for $S$. aureus and S. agalactiae, modifying the temperature gradient annealing, since the annealing temperature used by Straub et al. (1999), STAUR6 and STAUR4, was $64^{\circ} \mathrm{C}$, it is considered very high when compared to the temperature used for Chotár et al. (2006), $55^{\circ} \mathrm{C}$. It was observed that separately by testing concentrations of $10^{6}$ bacterias $/ \mathrm{mL}^{-1}$, the same amplification was obtained in all tested temperatures.

However, when analyzing the gradient temperature with all three pairs of primers together (STAUR4 and STAUR6, SIP3 and SIP4, and Ecol1 and Ecol2) and the three agents present at concentration of $10^{7}$ bacteria. $\mathrm{mL}^{-1}$, it was observed that the annealing temperature with better results in simultaneous detection of three agents was $64^{\circ} \mathrm{C}$, as described by Straub et al. (1999) for detecting by STAUR4 and STAUR6.

Using primers STAUR4 and STAUR6, SIP3 and SIP4, or Ecol1 and Ecol2 on individually PCR assays, and comparing the concentrations of primers, was observed that the use of primers in lower concentrations $(10 \mu \mathrm{M})$, as shown by Straub et al. (1999), showed better results (Fig.1), obtaining the 
respective analytical sensitivity for S. aureus: $10^{\circ}(10 \mu \mathrm{M})$ and $10^{2}(25 \mu \mathrm{M})$ bacteria.mL ${ }^{-1}$ goat milk samples. For S. agalactiae, the analytical sensitivity was $10^{0}(10 \mu \mathrm{M})$ and $10^{1}(25 \mu \mathrm{M})$ bacteria. $\mathrm{mL}^{-1}$ in milk samples, whereas for it was $10^{\circ}(10 \mathrm{um})$ and $10^{2}(25 \mu \mathrm{M})$ bacteria. $\mathrm{mL}^{-1}$ for E. coli. Another advantage observed for the detection of $S$. agalactiae was compared to the size of the base pairs observed on amplification with primers SAGA1 and SAGA2. These primers amplify a region of $660 \mathrm{bp}$, closed size to that amplicon produced by Ecol 1 and Ecol2 (590bp), which one can cause confusion on the analysis. As the set of primers SIP3 and SIP4 produces an amplicon 293bp, the confusion on the analysis can be avoided (Fig.1). The $10 \mu$ Mprimer concentration showed better results in comparison with the $25 \mu \mathrm{M}$ concentration, and was selected to be used in this study. When tested together on a multiplex-PCR, the set of primers SATUR4:STAUR6 (S. aureus), S1P3:SIP4 (S. agalactiae) and Ecol1:Ecol2 (E. coli) showed again better results than the others, by the use of $10 \mu \mathrm{M}$ each primer, and were selected to run multiplex-PCR on all 513 samples (Fig.2).

Multiplex-PCR detected 173 pathogens in 151/523 (28.9\%; CI95\% 25.2-32.9\%) milk samples [144/513 (28.1\%) hald-udders and 7/10 (70\%) bulk tanks], with the following frequency: E. coli $(86 / 162,51.9 \%)$, S. aureus $(50 / 162$, $30.9 \%)$ and $S$. agalactiae $(28 / 162,17.3 \%)$ in half-udders; and $S$. aureus $(6 / 10,60 \%)$ and $E$. coli $(4 / 5,36.4 \%)$ in bulk tanks. S. agalactiae presented negative results for all bulk tank samples. In this way, the prevalence of $S$. aureus ranged from 0 to $24.3 \%$, S. agalactiae from 2 to $17.4 \%$, and $E$. coli from 0 to $29.6 \%$ among the dairy goat farms (Table 2 ).

Analyzing just the bulk-tanks, the prevalence of $S$. aureus was $60 \%(6 / 10)$, S. agalactiae $10 \%(1 / 10)$ and E. coli $40 \%$ $(4 / 10)$ by multiplex-PCR, similar results to those observed by microbiological culture, with $70 \%(7 / 10)$ S. aureus, $50 \%$ (5/10) Enterobacteriaceae and 10\% (1/10) Streptococcus spp., presenting an almost perfect agreement $(\kappa=0.8618)$, when considering just the half-udders results, and multiplex-PCR presented a sensitivity of $84.6 \%$, specificity of $100 \%$, and positive and negative predictive values of $100 \%$ and $89.5 \%$, respectively. A low positive (30.9\%) and high negative (85.4\%) agreements were still observed between both tests. In other way, regarding to the half-udders a fair concordance was observed $(\kappa=0.2312)$, and multiplex-PCR presented a sensitivity of $87.5 \%$, specificity of $75.1 \%$, and positive and negative predictive values of $18.8 \%$ and $98.9 \%$, respectively. High positive (91.7\%) and negative (94.4\%) agreements were still observed between both tests.

Animals presenting co-infection were observed in seven farms by multiplex-PCR. Seventeen pathogens were detected causing co-infection. One animal from farm \# 7 presented all three studied pathogens. The most common co-infection was

Table 2. Frequency of Staphylococcus aureus, Streptococcus spp. and Enterobacteriaceae isolates by microbiological culture and multiplex-PCR for S. aureus, Streptococcus agalactiae and Escherichia coli in half-udders (hu) and status in bulk tanks (bt) of 10 dairy goat farms

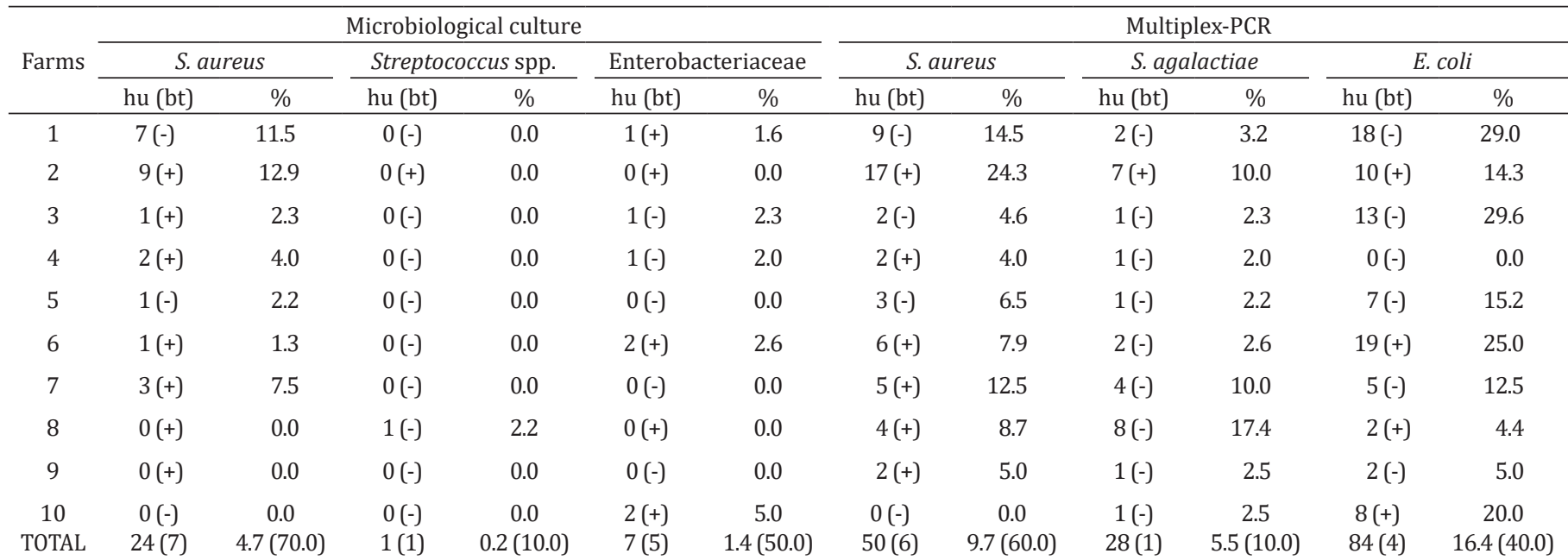

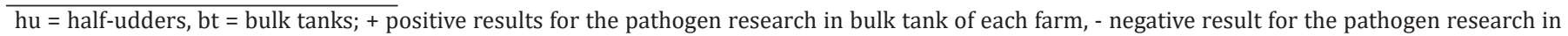
bulk tank of each farm.

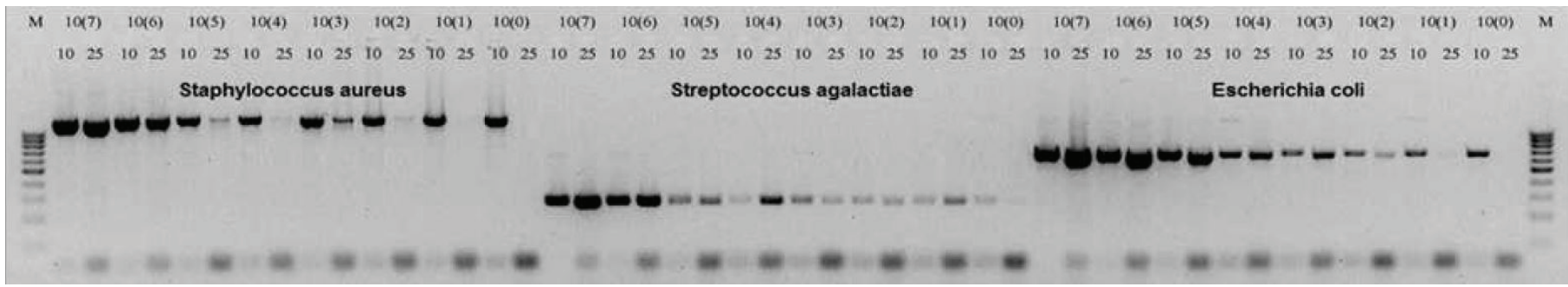

Fig.1. Detection threshold $\left(10^{7}\right.$ to $\left.10^{\circ}\right)$ separately using primers STAUR4 and STAUR6, SIP3 and SIP4, and Ecol1 and Ecol2 in different concentrations: $10 \mu \mathrm{M}$ according with Straub et al. (1999), 25 $\mu \mathrm{M}$ according Chotár et al. (2006) in goat milk sample, using the PCR protocol described by Straub et al. (1999). $M=$ molecular weight standard (100 base pairs). 


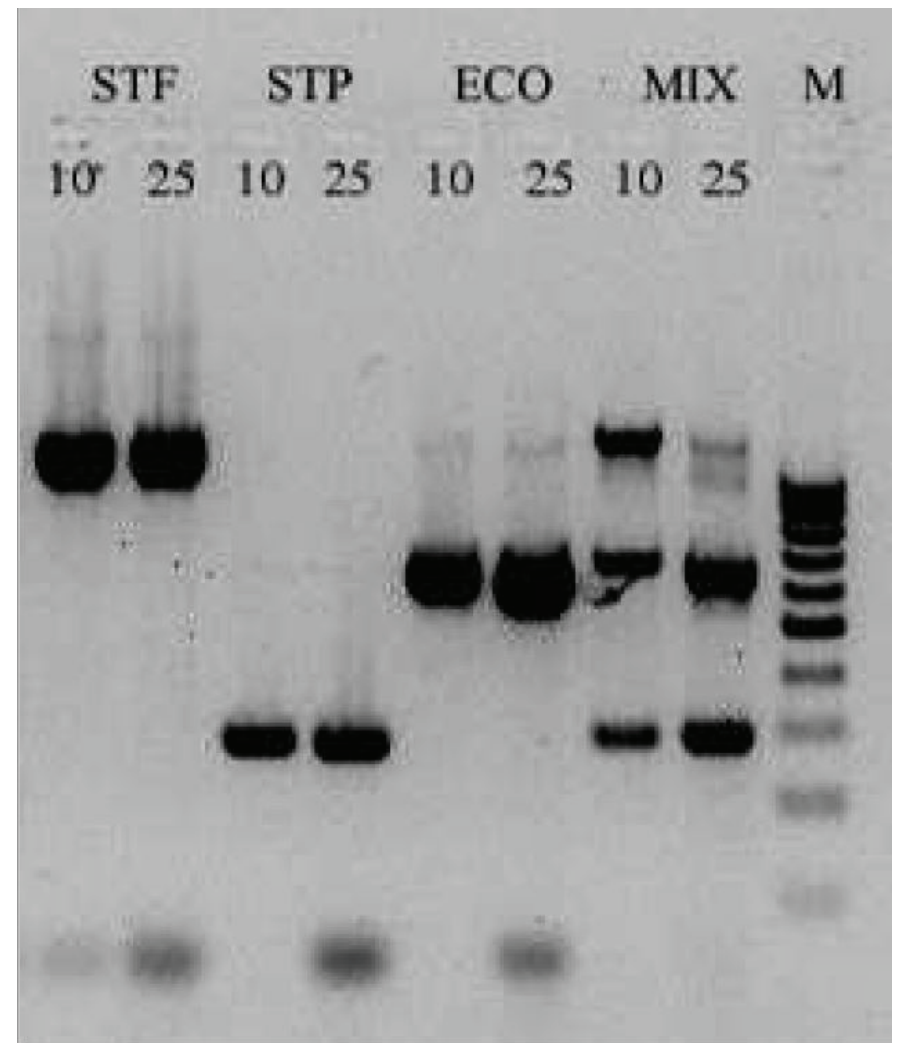

Fig.2. Multiplex-PCR with primers STAUR4 and STAUR6, SIP3 and SIP4, and Ecol1 and Ecol2 isolated and together, using various concentrations of primers: $10 \mu \mathrm{M}$ according with Straub et al. (1999), 25 $\mu \mathrm{M}$ according Chotár et al. (2006), in sample of goat milk. $\mathrm{M}=$ molecular weight standard (100 base pairs).

between $S$. aureus and E. coli $(10 / 17,58.8 \%)$ in six farms, followed by $S$. agalactiae and $E$. coli $(4 / 17,23.5 \%)$ in four farms, and $S$. aureus and S. agalactiae $(2 / 17,11.8 \%)$ in two farms.

\section{DISCUSSION}

A technique that has been used in an increasing order for bacterial identification is the multiplex-PCR, which uses more than one pair of primers in the same reaction, amplifying simultaneously various DNA sequences. This technique allows the identification of more than one bacterial species in the same PCR, promoting a more rapid and wide of pathogenic bacteria in food (Wilson et al. 1991). Thus, the objective was to research directly in the milk of 513 half-udders and 10 bulk tanks pathogens: Staphylococcus aureus, Streptococcus agalactiae and Escherichia coli.

Specific PCR was performed for each of the agents using the protocol and primers described by Chotár et al. (2006). By low analytical sensitivity observed for $S$. aureus and $S$. agalactiae, which may be suggested by low frequency copies of regions flanked by the primers SAU1 and SAU2, and SAGA1 and SAGA2, and was tested primers STAUR6 and STAUR4 described by Straub et al. (1999) for detection of S. aureus, and SIP3 and SIP4 described by Chotár et al. (2006) for detection of $S$. agalactiae.

Chotár et al. (2006) standardized multiplex-PCR protocol used previously, and attempt to reuse the same protocol modifying primers specific for S. aureus and S. agalactiae, we tested the temperature gradient annealing, since the annealing temperature used by Straub et al. (1999) for STAUR6 and STAUR4 to $64^{\circ} \mathrm{C}$, was considered very high in relation to the temperature used for Chotár et al. (2006), $55^{\circ} \mathrm{C}$, however, the temperature described by Straub et al. (1999) was the best result presented in the simultaneous detection of three agents.

Utilizing primers STAUR 4 and STAUR6, SIP3 and SIP4, and Ecol1 and Ecol2, and comparing the concentrations of primers, was observed that the use of primers in lower concentrations $(10 \mu \mathrm{M})$, as shown by Straub et al. (1999) showed better results (Table 1, Fig.2), obtaining analytical sensitivity in detecting S. aureus $10^{0}(10 \mu \mathrm{M})$ and $10^{2}(25 \mu \mathrm{M})$ bacterias $/ \mathrm{mL}^{-1}$ goat milk samples. For the detection of $S$. agalactiae, sensitivity to $10^{0}(10 \mu \mathrm{M})$ and $10^{1}(25 \mu \mathrm{M})$ bacterias $/ \mathrm{mL}^{-1}$ was obtained in samples of milk, while for Escherichia coli $10^{\circ}(10 \mu \mathrm{M})$ and $10^{2}(25 \mu \mathrm{M})$ bacterias $/ \mathrm{mL}^{-1}$.

The primers SIP3 and SIP4 produce an amplicon 293pb, different of the 660pb produced by SAGA1 and SAGA2, and $590 \mathrm{pb}$ produced by Ecol1 and Ecol2, no problem in the agarose gel analysis (Table 1).

The prevalent pathogens by multiplex-PCR in half-udders were E. coli $(16.4 \%)$, S. aureus $(9.7 \%)$ and S. agalactiae $(5.5 \%)$ and, in bulk tanks, S. aureus (60\%), E. coli (40\%) and S. agalactiae $(10 \%)$.

Of the 10 dairy goat farms that had the half-udders evaluated by microbiological culture, seven were isolated S. aureus, five were Enterobacteriaceae family and in only one was isolated Streptococcus spp., being correctly diagnosed by multiplex-PCR six bulk tanks with $S$. aureus, one with $S$. agalactiae and four E. coli. This shows the high sensitivity of the technique for the diagnosis of these pathogens and their applicability to monitoring the health of livestock and quality of milk bulk tanks. The prevalent pathogens by multiplex-PCR in half-udders were E. coli (16.4\%), S. aureus $(9.7 \%)$ and S. agalactiae (5.5\%) and, in bulk tanks, S. aureus (60\%), E. coli $(40 \%)$ and S. agalactiae (10\%).

The bulk tank of farm \#2 was positive for all three agents by the multiplex-PCR, however, the bulk tanks of the farms \#1, \#3 and \#5 were negative for all three bacteria. The absence of positive results for S. aureus, S. agalactiae and E. coli agreed to the results of the microbiological culture and reinforces the point that the sensitivity and specificity of molecular methods for the detection of bacterial pathogens in milk samples are closely related to both the characteristics of microorganisms, such as complexity of the cell wall, which may hinder lysis during the extraction of DNA, as well as the types of primers used (Cremonesi et al. 2006).

Microbiological culture of half-udders detected 24 positive samples for S. aureus, against 50 by multiplex-PCR. S. aureus is the most pathogenic infectious agent to the mammary gland of goats, both subclinical and clinical disease, its importance is evident in public health by the production of toxins, serving as an indicator of sanitary-hygiene in the food industry (Murray et al. 1992, Anderson et al. 2004).

Streptococcus spp. was diagnosed only by microbiological culture in just one half-udders milk sample, against 28 S. agalactiae positive results by multiplex-PCR. Sporadically, $S$. agalactiae causes mastitis in goats. The infection with this pathogen may result in fibrosis and decrease in milk production (Bergonier et al. 2003, Anderson et al. 2004). 
In the same way, E. coli detection presented higher sensitivity by multiplex-PCR (84 positive half-udders milk samples detected), when compared to the detection of Enterobacteriaceae family by microbiological culture (seven positive samples). E. coli can be found in organic matter (feces and soil), water, earth, air and animal bedding, and hardly will not be present in the milk of animals after milking (Smith \& Sherman 2009, Fuquay et al. 2011). The prevalence of infection with $E$. coli in goats is low, occurring mainly in the periods between milking, representing public health risk (Radostitis et al. 2007, Fuquay et al. 2011).

The multiplex-PCR technique standardized in this study showed an almost perfect agreement for the detection of $S$. aureus, S. agalactiae and E. coli in bulk tanks when compared to microbiological culture, but a fair one in goat half-udders milk samples. In other way, multiplex-PCR presented a high quality perfomance on the detection of real positive and negative results in goat milk samples obtained direct from the half-udders or bulk tanks, presenting at least high negative agreement for both type of samples, and a high positive agreement for bulk tank samples, when compared to the microbiological culture. Thus, the combined use of this technique with microbiological culture allows maximizing the sensitivity and specificity of technique, increasing the efficiency of the mastitis diagnosis on goats.

\section{CONCLUSIONS}

The standardized multiplex-PCR showed good accuracy for the detection of Staphylococcus aureus, Streptococcus agalactiae and Escherichia coli in mastitic goat milk directly of the mammary gland and bulk tanks.

As correct species identification is important for mastitis treatment, prevention, control and in epidemiological investigations, as well as to understand of the significance of infections caused by different bacterial species, this assay proved to be an adequate tool for the identification of the most common mastitis pathogens, independent of their phenotypic characteristics in the diagnosis of clinical mastitis, allowing a continuous and better vigilance and monitoring of the herd, which one could be included in quality programs.

Conflict of interest.- The authors declare no conflict of interest.

Acknowledgments.-We would like to thank the São Paulo Research Foundation (FAPESP) for PhD grant and financial support, Processes (\# 2010/17254-7) and (\# 2011/07107-0).

\section{REFERENCES}

Anderson D.E., Hull B.H. \& Pugh D.G. 2004. Enfermidades da glândula mamária, p.379-399. In: Pugh D.G. (Ed), Clínica de Ovinos e Caprinos, Roca, São Paulo.

Bergonier D., de Crémoux R., Rupp R., Lagriffoul G. \& Berthelot X. 2003. Mastitis of dairy small ruminants. Vet. Res. 34(5):689-716. http://dx.doi. org/10.1051/vetres:2003030. <PMid:14556701>

Capurro A., Artursson K., Waller K.P., Bengtsson B., Ericsson-Unnerstad H. \& Aspan A. 2009. Comparison of a commercialized phenotyping system, antimicrobial susceptibility testing, and tuf gene sequence-based genotyping for species-level identification of coagulase-negative staphylococci isolated from cases of bovine mastitis. Vet. Microbiol. 134(3/4):327-333. http:// dx.doi.org/10.1016/j.vetmic.2008.08.028. <PMid:18930604>

Chotár M., Vidova B. \& Godany A. 2006. Development of specific and rapid detection of bacterial pathogens in dairy products by PCR. Folia
Microbiologica 51(6):639-646. http://dx.doi.org/10.1007/BF02931632. <PMid:17455804>

Cremonesi P., Pisoni G., Severgnini M., Consolandi C., Moroni P., Raschetti M. \& Castiglioni B. 2009. Pathogen detection in milk samples by ligation detection reaction-mediated universal array method. J. Dairy Sci. 92(7):3027-3039. http://dx.doi.org/10.3168/jds.2008-1773. <PMid:19528580>

Cremonesi P., Castiglioni B., Malferrari G., Biunno I., Vimercati C., Moroni P., Morandi S. \& Luzzana M. 2006. Technical note: Improved method for rapid DNA extraction of mastitis pathogens directly from milk. J. Dairy Sci. 89(1):163-169. http://dx.doi.org/10.3168/jds.S0022-0302(06)72080-X. $<$ PMid:16357279>

Fuquay J.W., Fox P.F. \& McSweeney P.L.H. 2011. Encyclopedia of Dairy Sciences. 2nd ed. Elsevier Limited, London, p.652-660.

Ghebremedhin B., Layer F., Konig W. \& Konig B. 2008. Genetic classification and distinguishing of Staphylococcus species based on different partial gap, 16S rRNA, hsp60, rpoB, sodA, and tuf gene sequences. J. Clin. Microbiol. 46(3):1019-1025. http://dx.doi.org/10.1128/JCM.02058-07. $<$ PMid:18174295>

Graber H.U., Casey M.G., Naskova J., Steiner A. \& Schaeren W. 2007. Development of a highly sensitive and specific assay to detect Staphylococcus aureus in bovine mastitic milk. J. Dairy Sci. 90(10):4661-4669. http://dx.doi. org/10.3168/jds.2006-902. <PMid:17881687>

Günther J., Esch K., Poschadel N., Petzl W., Zerbe H., Mitterhuemer S., Blum H. \& Seyfert H.M. 2011. Comparative kinetics of Escherichia coli and Staphylococcus aureus-specific activation of key immune pathways in mammary epithelial cells demonstrates that $\mathrm{S}$. aureus elicits a delayed response dominated by interleukin-6 (IL-6) but not by IL-1A or tumor necrosis factor alpha. Infection Immunity 79(2):695-707. http://dx.doi. org/10.1128/IAI.01071-10. <PMid:21115717>

Koskinen M.T., Holopainen J., Pyorala S., Bredbacka P., Pitkala A., Barkema H.W., Bexiga R., Roberson J., Solverod L., Piccinini R., Kelton D., Lehmusto H., Niskala S. \& Salmikivi L. 2009. Analytical specificity and sensitivity of a real-time polymerase chain reaction assay for identification of bovine mastitis pathogens. J. Dairy Sci. 92(3):952-959. http://dx.doi.org/10.3168/ jds.2008-1549. <PMid:19233788>

Kuang Y., Tani K., Synnott A.J., Ohshima K., Higuchi H., Nagahata H. \& Tanji Y. 2009. Characterization of bacterial population of raw milk from bovine mastitis by culture-independent PCR-DGGE method. Biochemical Eng. J. 45(1):76-81. http://dx.doi.org/10.1016/j.bej.2009.02.010.

Little C.L., Rhoades J.R., Sagoo S.K., Harris J., Greenwood M., Mithani V., Grant K. \& McLauchlin J. 2008. Microbiological quality of retail cheeses made from raw, thermized or pasteurized milk in the UK. Food Microbiol. 25(2):304312. http://dx.doi.org/10.1016/j.fm.2007.10.007. <PMid:18206773>

Mackinnon A. 2000. A spreadsheet for the calculation of comprehensive statistics for the assessment of diagnostic tests and inter-rater agreement. Computers Biol. Med. 30(3):127-134. http://dx.doi.org/10.1016/S00104825(00)00006-8. <PMid:10758228>

Murray P.R., Drew W.L. \& Kobayashi G. 1992. Microbiologia Médica. GuanabaraKoogan, Rio de Janeiro, p.116-137.

Pyörälä S. \& Taponen S. 2009. Coagulase-negative staphylococci-emerging mastitis pathogens. Vet. Microbiol. 134(1/2):3-8. http://dx.doi.org/10.1016/j. vetmic.2008.09.015. <PMid:18848410>

Quinn P.J., Markey B., Carter M.E., Donnelly W.J. \& Leonard F.C. 2005. Microbiologia Veterinária e Doenças Infecciosas. Artmed, Porto Alegre, p.55-60.

Radostitis O.M., Gay C.C., Blood D.C. \& Hinchcliff K.W. 2007. Clínica Veterinária: um tratado de doenças dos bovinos, ovinos, suínos, caprinos e equinos. Guanabara-Koogan, Rio de Janeiro.

Riffon R., Sayasith K., Khalil H., Dubreuil P., Drolet M. \& Lagacé J. 2001. Development of a rapid and sensitive test for identification of major pathogens in bovine mastitis by PCR. J. Clin. Microbiol. 39(7):2584-2589. PMid:11427573. 
SAS Institute 2009. SAS/STAT User's Guide, Version 9.3. SAS Institute Inc., Cary.

Schukken Y.H., Gonzalez R.N., Tikofsky L.L., Schulte H.F., Santisteban C.G., Welcome F.L., Bennett G.J., Zurakowski M.J. \& Zadoks R.N. 2009. CNS mastitis: nothing to worry about? Vet. Microbiol. 134(1/2):9-14. http:// dx.doi.org/10.1016/j.vetmic.2008.09.014. <PMid:18842362>

Smith M.C. \& Sherman D.M. 2009. Goat Medicine. Willey and Blackwell, Ames, p.647-689. http://dx.doi.org/10.1002/9780813818825.

Straub J.A., Hertel C. \& Hammes W.P. 1999. A 23S rDNA-targeted polymerase chain reaction-based system for detection of Staphylococcus aureus in meat starter cultures and dairy products. J. Protection 62(10):1150-1156. http://dx.doi.org/10.4315/0362-028X-62.10.1150. <PMid:10528718>
Trabulsi L.R., Ordoñez J.G. \& Martinez M.B. 2005. Enterobacteriaceae, p.269-276. In: Trabulsi L.R. \& Alterthum F. (Eds), Microbiologia. 4를 ed. Atheneu, São Paulo.

Wilson I.G., Cooper J.E. \& Gilmour A. 1991. Detection of enterotoxigenic Staphylococcus aureus in dried skimmed milk: use of the polymerase chain reaction for amplification and detection of staphylococcal enterotoxin genes entB and entC1 and the thermonuclease gene nuc. Appl. Environ. Microbiol. 57(6):1793-1798. <PMid:1872609>

Zadoks R.N. \& Watts J.L. 2009. Species identification of coagulase-negative staphylococci: genotyping is superior to phenotyping. Vet. Microbiol. 134(1/2):20-28. http://dx.doi.org/10.1016/j.vetmic.2008.09.012. <PMid:18930607> 